\title{
THE USE OF AN INTRA-ORAL SCANNER FOR PATELLAR SURFACE ANALYSIS IN TOTAL KNEE ARTHROPLASTY
}

\author{
UPORABA INTRAORALNEGA SKENERJA ZA ANALIZO POVRŠIN \\ POGAČICE PRI TOTALNI ARTROPLASTIKI KOLENA
}

\author{
Klemen Bošnjak ${ }^{1,2 *}$, Boštjan Kocjančič1,2, Drago Dolinar ${ }^{1,2}$, Borut Pompe ${ }^{1,2}$ \\ ${ }^{1}$ University Medical Centre Ljubljana, Department of Orthopaedic Surgery, Zaloška cesta 9, 1000 Ljubljana, Slovenia \\ ${ }^{2}$ University of Ljubljana, Faculty of Medicine, Chair of Orthopaedics, Zaloška cesta 9, 1000 Ljubljana, Slovenia
}

Prejem rokopisa - received: 2020-06-09; sprejem za objavo - accepted for publication: 2020-07-27

doi:10.17222/mit.2020.115

\begin{abstract}
Using an intra-oral scanner for surface and contact evaluation is a novelty in orthopaedics. We introduced this method to compare the congruence between patellar and femoral component surfaces. The compared patellar surfaces were created either with resurfacing, retention of an un-resurfaced patella or patelloplasty, a reshaping method where both facets are resected to match the trochlear surface. In our prospective clinical study, two patients had their patellar surfaces scanned during knee endoprosthesis (Genesis II, Smith \& Nephew) implantation, using TRIOS® (3Shape) intraoral laser scanner. Each patient's patella was scanned three times. First, the original joint surface was scanned after arthrotomy, then scanned again after reshaping the patellar surface and finally scanned after resurfacing with the appropriate standard implant was performed. The acquired surface data were evaluated using CloudCompare software. A mathematical algorithm was used to achieve the best proximity between these surfaces. Distances between the surfaces were measured throughout $0-120^{\circ}$ of knee flexion. We defined the measure of proximity as "contact area magnitude". On average, the contact area magnitude was $2.91 \pm 0.82 \mathrm{~mm}$ using the un-resurfacing method, $3.19 \pm 0.95 \mathrm{~mm}$ using the resurfaced method and $3.84 \pm 0.91 \mathrm{~mm}$ using patelloplasty. Leaving the patella un-resurfaced resulted in an improved contact area magnitude. The proximity of the surfaces increased with knee flexion until $75^{\circ}$. With this study, the use of an intra-oral scanner for the surface analysis and intraoperative congruence evaluation was demonstrated. This method could contribute to a better understanding of patellofemoral congruence during total knee arthroplasty.

Keywords: total knee arthroplasty, patellofemoral congruency, laser surface scanning
\end{abstract}

Uporaba intraoralnega skenerja za oceno površin in kontakta med njimi je novost $\mathrm{v}$ ortopediji. To metodo smo uvedli za primerjavo kongruence med površino pogačice in stegnenične komponente. Površine pogačice, ki smo jih primerjali so bile pridobljene $\mathrm{z}$ artroplastično preplastitvijo pogačice, ohranitvijo pogačice ali pateloplastiko, metodo preoblikovanja, pri katerem obe ploskvi reseciramo tako, da se ujemata s površino trohlee. V naši prospektivni klinični študiji sta bila dva bolnika tekom implantacije kolenske endoproteze (Genesis II, Smith in Nephew), skenirana z intraoralnim laserskim skenerjem TRIOS® (3Shape). Vsako bolnikovo površino pogačice smo skenirali trikrat. Najprej smo skenirali prvotno površino sklepa, nato ponovno po preoblikovanju površine s pateloplastiko in nazadnje še po endoprotetični preplastitvi pogačice. Pridobljeni podatki so bili obdelani s programsko opremo CloudCompare. Za doseganje maksimalnega prileganja teh površin, smo uporabili matematični algoritem. Razdalje med proučevanimi površinami so bile izmerjene skozi celoten obseg $0-120^{\circ}$ fleksije kolena. Ujemanje površin smo opredelili s pomočjo razdalje med njimi, dobljeno mero kongruence pa opredelili kot "stopnjo kontaktnega območja". V povprečju je bila stopnja kontaktnega območja $2,91 \pm 0,82 \mathrm{~mm}$ pri ohranjeni površini pogačice, $3,19 \pm 0,95 \mathrm{~mm}$ pri preplastitvi pogačice in $3,84 \pm 0,91 \mathrm{~mm}$ pri pateloplastiki. Ohranitev površine pogačice, je izboljšala njeno ujemanje s stegnenično komponento. Ujemanje se je $\mathrm{z}$ upogibanjem kolena povečalo do $75^{\circ}$. $\mathrm{S}$ to študijo smo prikazali uporabnost intraoralnega skenerja za površinsko analizo in intraoperativno oceno ujemanja površin. Prikazana metoda bi lahko prispevala $\mathrm{k}$ boljšemu razumevanju patelofemoralne kongruence pri totalni artroplastiki kolena.

Ključne besede: totalna artroplastika kolena, patelofemoralna kongruenca, skeniranje površin z laserjem

\section{INTRODUCTION}

The correct method of patellar surface management during a total knee arthroplasty (TKA) is still unclear and this topic is regarded as controversial. Patellofemoral complications represent the most common cause leading to a TKA revision surgery, as bearing surface forces and contact patterns generated at the patellofemoral joint alter after TKA compared to the normal knee. ${ }^{1-3}$ To avoid these complications and improve the outcome, reports highlighting the importance of patellofemoral congruity have emerged..$^{4-6}$ These authors put the emphasis on the correct shaping of the patellar surface and the choice of

*Corresponding author's e-mail:

klemen.bosnjak@gmail.com (Klemen Bošnjak) an adequately fitting femoral component design. ${ }^{1,5}$ It has been reported that sharper facet-angled patellae produce larger postoperative patellar tilt angles, and lead to progressive patellar osteosclerosis, which is suggestive of higher patellofemoral joint pressures, malalignment and osteoarthritis progression. ${ }^{4,6}$ However, the relationship between patellofemoral joint congruence and the clinical outcome after a TKA procedure is not well established in the literature and clinical studies are needed to address this issue. ${ }^{7-9}$ As the shape of the chosen femoral implant remains identical, emphasis has been given to the optimal method of patellar management. ${ }^{6,7}$ In this article we will demonstrate the use of a new tool in the postoperative patellar surface congruity evaluation of the two most 
widespread methods, i.e., patellar resurfacing and un-resurfacing, together with the method of patelloplasty.

The established methods of patellar management are presented in more detail. The most frequently performed one is resurfacing, as many surgeons prefer to practice this method routinely, with the purpose of lowering the anterior knee pain..$^{3,10}$ Although revision rates with resurfacing are low, the causes leading to them are severe: patellar fracture, osteonecrosis, polyethylene wear, instability, aseptic loosening, dislocation, rupture of the extensor mechanism ${ }^{2,10}$ In contrast, some authors report similar long-term results regarding patient satisfaction, functional and knee pain outcomes in resurfacing and un-resurfacing. ${ }^{2,11}$ Therefore, to avoid severe complications, some prefer retaining the patella over resurfacing. ${ }^{2,11}$ The management with patelloplasty, proposed by some surgeons, includes osteophyte removal and the resection of patellar facets with tangential cuts, trimming and shaping the patella to match the trochlea of the femoral component. ${ }^{7,12}$ A. Župan et al. ${ }^{12}$ found higher patient satisfaction and lower knee pain outcomes with patelloplasty, compared to un-resurfacing. Some surgeons, however, found no differences between patellar resurfacing and patelloplasty in terms of patient satisfaction and knee pain outcomes, but prefer patelloplasty to preserve the bone stock. ${ }^{7}$

We have chosen a new tool to determine which method of patellar management during TKA results in the best patellofemoral congruence. Our aim was to demonstrate the use of an intraoral scanner for surface analysis and congruence evaluation. As a measure of congruence, the proximity between the surfaces was used. We have defined this distance as the "contact area magnitude". The use of this scanner in orthopaedics has not yet been presented in the literature. We hypothesized that different congruence can be achieved with resurfacing, un-resurfacing or patelloplasty.

\section{MATERIALS AND METHODS}

\subsection{Study participants}

We selected two patients with degenerative osteoarthritis of the knee joint who underwent a TKA (Genesis II, Smith \& Nephew, Memphis Tennessee, USA) in January 2016 at our institution. The following exclusion criteria were applied: previous surgical procedures on the knee joint involving the extensor mechanism, rheumatoid diseases, osteoporosis, history of patellar fracture or instability, non-degenerative related preoperative surface pathologies of the knee joint and valgus or varus deformity greater than $15^{\circ}$. Informed consent was obtained from both participants.

\subsection{Surgical procedure}

The operations were performed by the same orthopaedic surgeon (B.P.), using the same method of patellar management and implanting the same size of femoral component. At the beginning of the procedure a tourniquet was applied and switched on for the entire duration. Using the medial parapatellar approach, the patella was everted and denervated. The surface of the un-resurfaced patella was scanned using the TRIOS ${ }^{\circledR}$ intraoral laser scanner (3Shape, Copenhagen, Denmark). Next, the surface was removed with two tangential cuts, thus creating two facets that intersected at an angle of approximately $130^{\circ}$. The surface managed with patelloplasty was then scanned using the same intraoral laser. After that, the managed patellar surface was cut off and a dome polyethylene button was positioned medially, creating a resurfaced surface and the patellar surface was scanned again.

\subsection{Surface analysis}

We used an intraoral scanner, which produces accurate depictions of the scanned surface with an in-vivo precision of 37.9-99.1 $\mu \mathrm{m} .{ }^{13}$ The scanner uses laser and surface pattern video recognition technology to evaluate different types of surfaces. ${ }^{14,15}$ The scanned data were then converted and imported into a computer program, where it represented a precise three-dimensional reconstruction of the surface. ${ }^{13-15}$ The data of the femoral component and the polyethylene button were provided by Smith \& Nephew. For the computer analysis, Cloud Compare software version 2.6.2. (EDF, Paris, France) was used. We compared congruence between the femoral component surface and the patellar surface: un-resurfaced, resurfaced and following patelloplasty. As a measure of congruence, the mean distance with standard deviation (SD) between the surfaces was used. Using surface proximity as a measure of congruence has been proposed by many authors. ${ }^{16,17}$ In our study we have defined this measure as "contact area magnitude". To achieve better contact area magnitude, we minimized the distances between the two surfaces using a mathematical algorithm. ${ }^{18}$ With reference to G.Windisch et al., ${ }^{16}$ we disabled the intersections and overlapping of surfaces. All the structures were assumed to be rigid with frictionless contact between them. Using a computer simulation, congruence was compared for each $15^{\circ}$ of knee flexion throughout the range of $0-120^{\circ}$. The kinematics of patellar movement was defined through a fem-

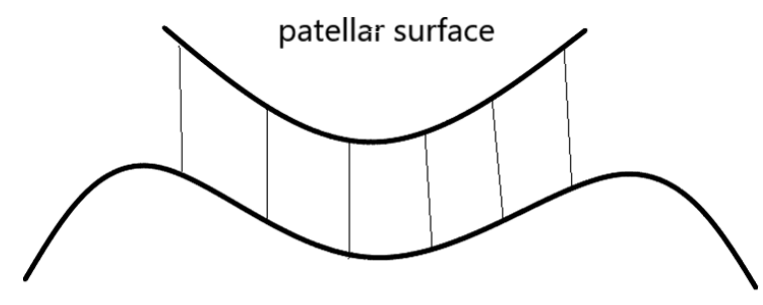

femoral component surface

Figure 1: An example of distance distribution between the un-resurfaced patellar and femoral surfaces at $60^{\circ}$ of knee flexion. The distribution is given as normal distribution. (Count) - quantity of distances, (C2M signed distances) - length of distances given in millimetres 


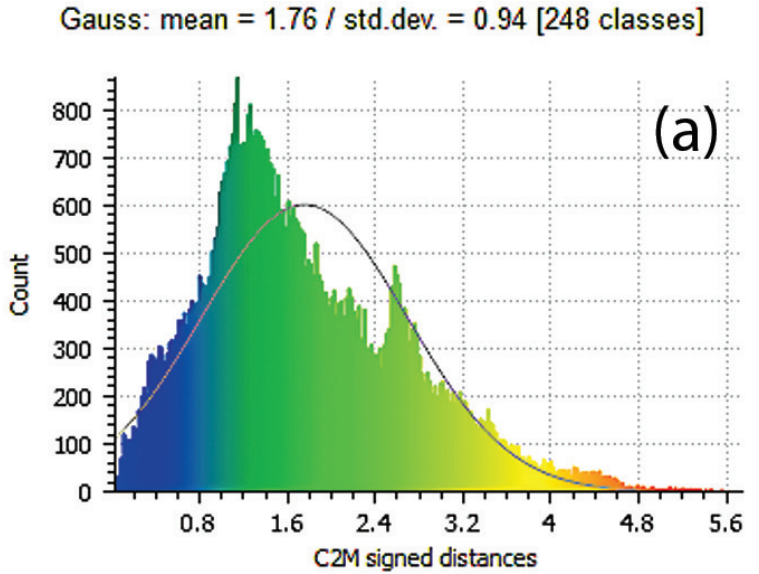

Legend:

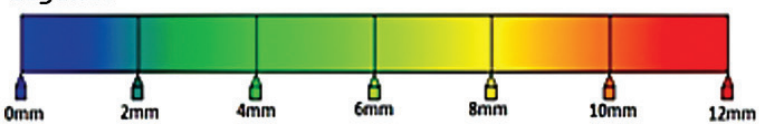

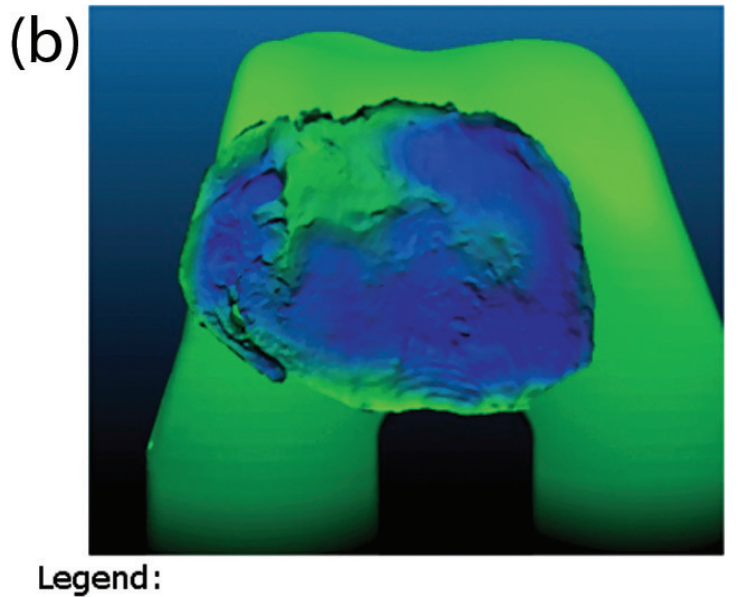

Legend:

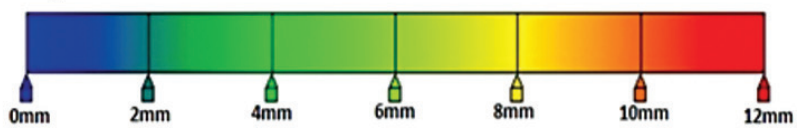

Figure 2: a) An example of graphical distance evaluation between the un-resurfaced patellar and femoral surfaces at $60^{\circ}$ of knee flexion, b) superposition of the un-resurfaced patella on femoral surfaces of the knee endoprothesis

oral coordinate system, based on Grood and Suntay's definition. ${ }^{19}$ The patellar starting position and kinematics were supervised under the guidance of an orthopaedic surgeon, as proposed in the literature. ${ }^{20}$ The gathered data were numerical and normally distributed (Figure 1).

For a visual evaluation the software was used to produce a colour-coded map superimposed on the patellar surface. The distances were divided into 2-mm intervals, each represented by different colour coding (Figure 2a and $\mathbf{2 b}$ ).

\subsection{Statistical analysis}

A statistical analysis was made using SPSS software version 20.0 (SPSS Inc., Chicago, IL, USA). For the intergroup comparison between the types of surfaces a one-way analysis of variance (ANOVA) was used for each dependent variable: congruence magnitude in un-resurfaced, resurfaced and patelloplasty groups. Intergroup comparisons were made in $15^{\circ}$ intervals, throughout the range of $0-120^{\circ}$ of knee flexion. Results were considered significant at $p<0,05$.

\subsection{Compliance with ethical standards}

All procedures performed in the study involving human participants were in accordance with the 1964 Helsinki declaration and its later amendments and were reviewed by National Medical Ethics Committee. Informed consent was obtained from both participants included in the study.

\section{RESULTS}

The lowest contact area magnitude and therefore the highest congruence in intergroup comparison was achieved with the method of un-resurfacing during $15-120^{\circ}$ and with the method of resurfacing at $0^{\circ}$ (Table 1, Figure 3). The highest contact area magnitude

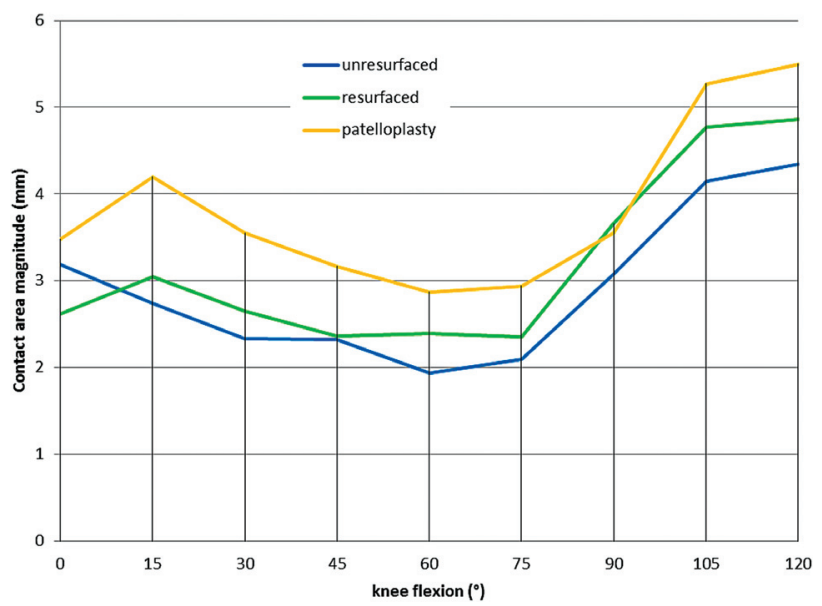

Figure 3: Contact area magnitude between the patellar surface type and the femoral component at different flexion angles. $(\mathrm{mm})$ - numerical data in millimetres, $\left(^{\circ}\right)$ - numerical data in angle degrees

Table 1: Mean contact area magnitude between the patellar surface type and the femoral component at different flexion angles. The values are given in millimetres as mean and standard deviation $(\# \pm \mathrm{SD})$

\begin{tabular}{|c|c|c|c|}
\hline \multirow{2}{*}{$\begin{array}{c}\text { Degree of } \\
\text { flexion }\end{array}$} & \multicolumn{3}{|c|}{ Type of patellar surface } \\
\cline { 2 - 4 } & Un-resurfaced & Resurfaced & Patelloplasty \\
\hline $0^{\circ}$ & $3.19 \pm 2.43^{\mathrm{a}}$ & $2.62 \pm 1.90^{\mathrm{a}}$ & $3.48 \pm 2.41^{\mathrm{a}}$ \\
\hline $15^{\circ}$ & $2.74 \pm 1.94^{\mathrm{a}}$ & $3.05 \pm 2.47^{\mathrm{a}}$ & $4.20 \pm 2.32^{\mathrm{a}}$ \\
\hline $30^{\circ}$ & $2.33 \pm 1.66^{\mathrm{a}}$ & $2.65 \pm 2.30^{\mathrm{a}}$ & $3.55 \pm 2.02^{\mathrm{a}}$ \\
\hline $45^{\circ}$ & $2.32 \pm 1.29^{\mathrm{a}}$ & $2.36 \pm 2.09^{\mathrm{a}}$ & $3.17 \pm 1.79^{\mathrm{a}}$ \\
\hline $60^{\circ}$ & $1.94 \pm 1.14^{\mathrm{a}}$ & $2.39 \pm 2.11^{\mathrm{a}}$ & $2.87 \pm 1.54^{\mathrm{a}}$ \\
\hline $75^{\circ}$ & $2.09 \pm 1.45^{\mathrm{a}}$ & $2.35 \pm 2.31^{\mathrm{a}}$ & $2.94 \pm 1.89^{\mathrm{a}}$ \\
\hline $90^{\circ}$ & $3.08 \pm 2.24^{\mathrm{a}}$ & $3.66 \pm 2.70^{\mathrm{a}}$ & $3.55 \pm 2.66^{\mathrm{a}}$ \\
\hline $105^{\circ}$ & $4.15 \pm 2.55^{\mathrm{a}}$ & $4.77 \pm 3.43^{\mathrm{a}}$ & $5.27 \pm 3.28^{\mathrm{a}}$ \\
\hline $120^{\circ}$ & $4.35 \pm 2.67^{\mathrm{a}}$ & $4.86 \pm 3.42^{\mathrm{a}}$ & $5.50 \pm 3.37^{\mathrm{a}}$ \\
\hline
\end{tabular}

${ }^{a}$ Values are statistically significant, with $p<0.001$ 
and therefore the lowest congruence overall was achieved with patelloplasty, except at $90^{\circ}$, where it was achieved with resurfacing (Table 1, Figure 3).

\section{DISCUSSION}

Congruence between joint surfaces is important. In biomechanical and cadaveric studies it strongly correlated with knee joint force distribution and stress generation. ${ }^{20-23}$ It is suggested that highly congruent surfaces of the patella and femur contribute to lower wear and knee pain. ${ }^{4,5,20}$ However, there is no clear evidence that improved patellofemoral congruence correlates with the reduction of knee pain after TKA. ${ }^{7-9}$ The origin of knee pain is considered to be multifactorial. ${ }^{3,8,23}$ A.Takahashi et al. ${ }^{4}$ demonstrated that morphologically incongruent patellae produce higher stress concentrations at the point of femoral contact and cause significantly more degenerative changes in the underlying subchondral bone tissue. A. Inoue et al. ${ }^{6}$ additionally demonstrated the importance of pre-operative patellar shape evaluation by reporting on increased patellar tilting and poor alignment of surfaces where the femoral component and patella were incongruent. Surgical technique and prosthesis design are therefore considered the most important factors affecting the extent of this problem. ${ }^{4,5,8}$

The relatively novel method of patellar reshaping, where the bone is cut tangentially to match the surface of the femoral component, produced the least congruent surfaces in our study. Steeper facets and an inclination to tilting were observed on the new patelloplasty-formed surfaces. In contrast, the un-resurfaced patella achieved the highest congruence at every degree of flexion, except $0^{\circ}$. S. Matsuda et al. ${ }^{21}$ reported that a patellar component with steeper facets can seat correctly only over a small portion of the trochlea. Furthermore, A. Inoue et al. ${ }^{6}$ reported poor patellofemoral alignment and in steeper facet-angled patellae postoperatively. Our results can therefore be supported by these reviews.

Only a few studies in the literature reported the use of optic or laser technology to analyse the joint surface geometry. ${ }^{5,16}$ In the study conducted by H. M. Ma et al., patellar and femoral component surfaces were scanned using a topometric sensor and congruence was measured on a 3-dimensional model with tangential line intersections. ${ }^{5}$ De Santis et al. ${ }^{23}$ reported on the use of a laser scanner in conjunction with video texturing technology and computer software simulation for a surface contact comparison of the tibiofemoral area in a porcine model..$^{23}$ G. Windisch et al. ${ }^{16}$ used a laser scanner to scan the tibiotalar articular surfaces and computer software to measure congruence with distance calculations similar to the one presented in our study. No study to date has reported the use of an intraoral scanner to analyse patellofemoral surface congruence. Mostly, intraoral scanners are used in dentistry as an alternative to conventional physical impression taking in implant reconstruc- tions. ${ }^{24}$ In the literature the accuracy of intraoral scanners is reported by comparing differences between a plaster model and surfaces generated with an in vivo scan. ${ }^{13,25}$ The accuracy for this scanner, ranging from $38 \mu \mathrm{m}$ to 99 $\mu \mathrm{m}$, has therefore been mostly validated for teeth. ${ }^{13-15}$ Additional factors, such as the operator's experience and the environment are reported to affect accuracy. ${ }^{24,25}$ P. Muller et al. ${ }^{24}$ reported on the differences in accuracy ranging from $8 \mu \mathrm{m}$ to $35 \mu \mathrm{m}$ between three separate scanning techniques using the TRIOS intraoral scanner. ${ }^{24}$ However, the viability and accuracy of scans made on cartilaginous tissue have yet to be evaluated. ${ }^{26}$

The present study has several limitations. As its results are based on representations from a mathematical model, it is impossible to predict its value in an in-vivo system. For our representative surfaces of the patellae, the analysis was conducted with only two patients. Our model represents ideal contact mechanics and our measure of congruence, the contact area magnitude, must be considered as a measure achieved under these given circumstances. We did not consider the effect of muscle and ligament-based forces during flexion and did not account for compression or different elastic modules of the materials. The effects of rotational positioning of the femoral component could not be simulated with our model. We were also unable to account for changes of the biological in-vivo stress adaptation, which remodels surfaces and can improve the congruence. ${ }^{2}$

\section{CONCLUSION}

With this study we have demonstrated the use of an intraoral scanner in obtaining joint surface information. Knowledge of intraoperative patellofemoral congruence and contact areas can contribute to new decisions in surgical planning regarding patellar management, and therefore, influence TKA success. Patellofemoral surface congruence could have an effect on patellar alignment, pressure distribution and osteoarthrosis progression, but other factors such as correct implant positioning and surgical technique, precise soft-tissue balance, choice of femoral component design, grade of diseased cartilage and patient weight and height are also associated with it. ${ }^{3-6}$ Therefore, further studies will be needed to evaluate the value of our results.

\section{Acknowledgements}

We thank our colleagues Iztok Križnar, D.D.S., Minko Križnar, dental technologist and Aleš Križnar, dental technologist from Iztok Križnar dental practice who provided the TRIOS® intra-oral laser scanner (3Shape) and helped with the image acquisition process, thus making this study possible. We are grateful to Blaž Vidmar, geodetic engineer for assistance with the Cloud Compare software computer analysis. We thank Luka Botolin, product manager digiCEN from TECOS, Slo- 
venian Tool and Die Development Center for consultancy regarding three-dimensional surface analysis. We also thank Aleš Troha, D.M.D. who contributed the idea of the study.

\section{Conflicts of interest}

Authors declare that they have no conflict of interest.

\section{REFERENCES}

${ }^{1}$ C. Becher, T. J. Heyse, N. Kron, S. Ostermeier, C. Hurschler, M. D. Schofer, S. Fuchs-Winkelmann, C.O. Tibesku, Posterior stabilized TKA reduce patellofemoral contact pressure compared with cruciate retaining TKA in vitro, Knee Surg Sports Traumatol Arthrosc., 17 (2009) 1159-65, doi:10.1007/s00167-009-0768-2

${ }^{2}$ P. A. Keblish, A. K. Varma, A. S. Greenwald, Patellar resurfacing or retention in total knee arthroplasty. A prospective study of patients with bilateral replacements, J Bone Joint Surg Br., 76 (1994) 930-7

${ }^{3}$ A. D. Boyd Jr, F. C. Ewald, W. H. Thomas, R. Poss, C. B. Sledge, Long-term complications after total knee arthroplasty with or without resurfacing of the patella, J Bone Joint Surg Am., 75 (1993) 674-81, doi:10.2106/00004623-199305000-00006

${ }^{4}$ A. Takahashi, H. Sano, M. Ohnuma, M. Kashiwaba, D. Chiba, M Kamimura, T. Sugita, E. Itoi, Patellar morphology and femoral component geometry influence patellofemoral contact stress in total knee arthroplasty without patellar resurfacing, Knee Surg Sports Traumatol Arthrosc., 20 (2012) 1787-95, doi:10.1007/s00167011-1768-6

${ }^{5}$ H. M. Ma, Y. C. Lu, T. G. Kwok, F. Y. Ho, C. Y. Huang, C. H. Huang, The effect of the design of the femoral component on the conformity of the patellofemoral joint in total knee replacement, $\mathrm{J}$ Bone Joint Surg Br., 89 (2007) 408-12, doi:10.1302/0301-620X. 89B3.18276

${ }^{6}$ A. Inoue, Y. Arai, S. Nakagawa, H. Inoue, Y. Yoshihara, S. Yamazoe, T. Kubo, Differences in patellofemoral alignment as a result of patellar shape in cruciate-retaining total knee arthroplasty without patellar resurfacing at a minimum three-year follow-up, Knee., 24 (2017) 1448-53, doi:10.1016/j.knee.2017.08.050

${ }^{7}$ Z. T. Liu, P. L. Fu, H. S. Wu, Y. Zhu, Patellar reshaping versus resurfacing in total knee arthroplasty - Results of a randomized prospective trial at a minimum of 7 years' follow-up, Knee., 19 (2012) 198-202, doi:10.1016/j.knee.2011.03.004

${ }^{8}$ D. Shervin, K. Pratt, T. Healey, S. Nguyen, W. M. Mihalko, M. M. El-Othmani, K. J. Saleh, Anterior knee pain following primary total knee arthroplasty, World J Orthop., 6 (2015) 795-803, doi:10.5312/ wjo.v6.i10.795

${ }^{9}$ A. Senioris, M. Saffarini, S. Rahali, L. Malekpour, F. Dujardin, O. Courage, Does patellofemoral congruence following total knee arthroplasty correlate with pain or function? Intraoperative arthroscopic assessment of 30 cases, Ann Transl Med., 4 (2016) 279, doi:10.21037/atm.2016.07.21

${ }^{10}$ D. J. Wood, A. J. Smith, D. Collopy, B. White, B. Brankov, M. K. Bulsara, Patellar resurfacing in total knee arthroplasty: a prospective, randomized trial, J Bone Joint Surg Am., 84 (2002) 187-93, doi:10.2106/00004623-200202000-00004
${ }^{11}$ J. A. Feller, R. J. Bartlett, D. M. Lang, Patellar resurfacing versus retention in total knee arthroplasty, J Bone Joint Surg Br., 78 (1996) 226-8

${ }^{12}$ A. Župan, Ž. Snoj, V. Antolič, B. Pompe, Better results with patelloplasty compared to traditional total knee arthroplasty, Int Orthop., 38 (2014) 1621-5, doi:10.1007/s00264-014-2366-2

${ }^{13}$ S. B. Patzelt, A. Emmanouilidi, S. Stampf, J. R. Strub, W. Att, Accuracy of full-arch scans using intraoral scanners, Clin Oral Investig., 18 (2014) 1687-94, doi:10.1007/s00784-013-1132-y

${ }^{14}$ S. Akyalcin, B. E. Cozad, J. D. English, C. D. Colville, S. Laman, Diagnostic accuracy of impression-free digital models, Am J Orthod Dentofacial Orthop., 144 (2013) 916-22, doi:10.1016/j.ajodo.2013. 04.024

${ }^{15}$ R. G. Nedelcu, A. S. Persson, Scanning accuracy and precision in 4 intraoral scanners: an in vitro comparison based on 3-dimensional analysis, J Prosthet Dent., 112 (2014) 1461-71, doi:10.1016/ j.prosdent.2014.05.027

${ }^{16}$ G. Windisch, B. Odehnal, R. Reimann, F. Anderhuber, H. Stachel, Contact areas of the tibiotalar joint, J Orthop Res., 25 (2017) 1481-7, doi:10.1002/jor.20429

${ }^{17}$ H. C. Hsu, Z. P. Luo, J. A. Rand, K. N. An, Influence of lateral release on patellar tracking and patellofemoral contact characteristics after total knee arthroplasty, J Arthroplasty., 12 (1997) 74-83, doi:10.1016/s0883-5403(97)90051-6

${ }^{18}$ C. R. Maurer, G. B. Aboutanos, B. M. Dawant, R. J. Maciunas, J. M. Fitzpatrick, Registration of 3-D images using weighted geometrical features, IEEE Trans Med Imaging., 15 (1996) 836-49, doi:10.1109/ 42.544501

${ }^{19}$ E. S. Grood, W. J. Suntay, A joint coordinate system for the clinical description of three-dimensional motions: application to the knee, J Biomech Eng., 105 (1982) 136-44, doi:10.1115/1.3138397

${ }^{20}$ C. K. Fitzpatrick, P. J. Rullkoetter, Influence of patellofemoral articular geometry and material on mechanics of the unresurfaced patella, J Biomech., 45 (2012) 1909-15, doi:10.1016/j.jbiomech.2012.05.028

${ }^{21}$ S. Matsuda, T. Ishinishi, S. E. White, L.A. Whiteside, Patellofemoral joint after total knee arthroplasty. Effect on contact area and contact stress, J Arthroplasty., 12 (1997) 790-7, doi:10.1016/s0883-5403(97) 90010-3

${ }^{22}$ B. Mavčič, V. Antolič, R. Brand, A. Iglič, V. Kralj-Iglič, D. R. Pedersen, Peak contact stress in human hip during gait, Pflugers Arch., 440 (2000) R177-8, doi:10.1007/s004240000054

${ }^{23}$ R. De Santis, A. Gloria, S. Viglione, S. Maietta, F. Nappi, L. Ambrosio, D. Ronca, 3D laser scanning in conjunction with surface texturing to evaluate shift and reduction of the tibiofemoral contact area after meniscectomy, J Mech Behav Biomed Mater., 88 (2018) 41-7, doi:10.1016/j.jmbbm.2018.08.007

${ }^{24}$ P. Müller, A. Ender, T. Joda, J. Katsoulis, Impact of digital intraoral scan strategies on the impression accuracy using the TRIOS Pod scanner, Quintessence Int., 47 (2016) 343-9, doi:10.3290/j.qi.a35524

${ }^{25}$ R. Richert, A. Goujat, L. Venet, G. Viguie, S. Viennot, P. Robinson, J. C. Farges, M. Fages, M. Ducret, Intraoral Scanner Technologies: A Review to Make a Successful Impression, J Healthc Eng., 2017 (2017) 8427595, doi:10.1155/2017/8427595

${ }^{26}$ B. Mavčič, B. Babnik, A. Iglič, M. Kandušer, T. Slivnik, V. KraljIglič, Shape transformation of giant phospholipid vesicles at high concentrations of $\mathrm{C}_{12} \mathrm{E}_{8}$, Bioelectrochemistry., 63 (2004), 183-7, doi:10.1016/j.bioelechem.2003.09.022 